\title{
The First D/V Chikyu IODP Operations: Successful Logging and Coring During NanTroSEIZE Stage 1 Expeditions
}

\author{
Shin'ichi Kuramoto, Daniel Curewitz, Moe Kyaw Thu, Hideki Masago, \\ and the Exp. 314, 315, and 316 Science Parties
}

The Nankai Trough Seismogenic Zone Experiment (NanTroSEIZE) is a multi-expedition IODP drilling project aimed at drilling, coring, logging, and instrumenting the seismogenic zone of an active subduction margin, in a region thought to generate megathrust earthquakes of magnitude $>8.0$ on the moment-magnitude scale (Tobin and Kinoshita, 2006). The Nankai Trough, offshore of the Kii Peninsula, Honshu, Japan (Fig. 1) was chosen as the location for this project based on a number of scientific drilling proposals to IODP. These reviewed existing drilling data in the region, the long-term historical and recent record of great earthquakes, the social and societal relevance of the area, and the accessibility of the seismogenic zone to present drilling technology. The first stage of this multi-stage project was intended to accomplish a broad characterization of the shallow geology, geophysics, physical properties, heat flow, and fluid flow in a transect across the downgoing Philippine Sea Plate, the toe of the Nankai accretionary prism, the megasplay fault zone region on the continental slope, and the Kumano Basin that lies between the accretionary prism and the Kii Peninsula, on the continental shelf (Fig. 2).

Between September 2007 and February 2008, IODP Expeditions 314, 315, and 316 were carried out in order to complete Stage 1 of the NanTroSEIZE; operations included Logging While Drilling (LWD), coring, and downhole measurement at eight sites (thirty-three holes) in the Nankai Trough accretionary prism. On 21 September 2007, Chikyu

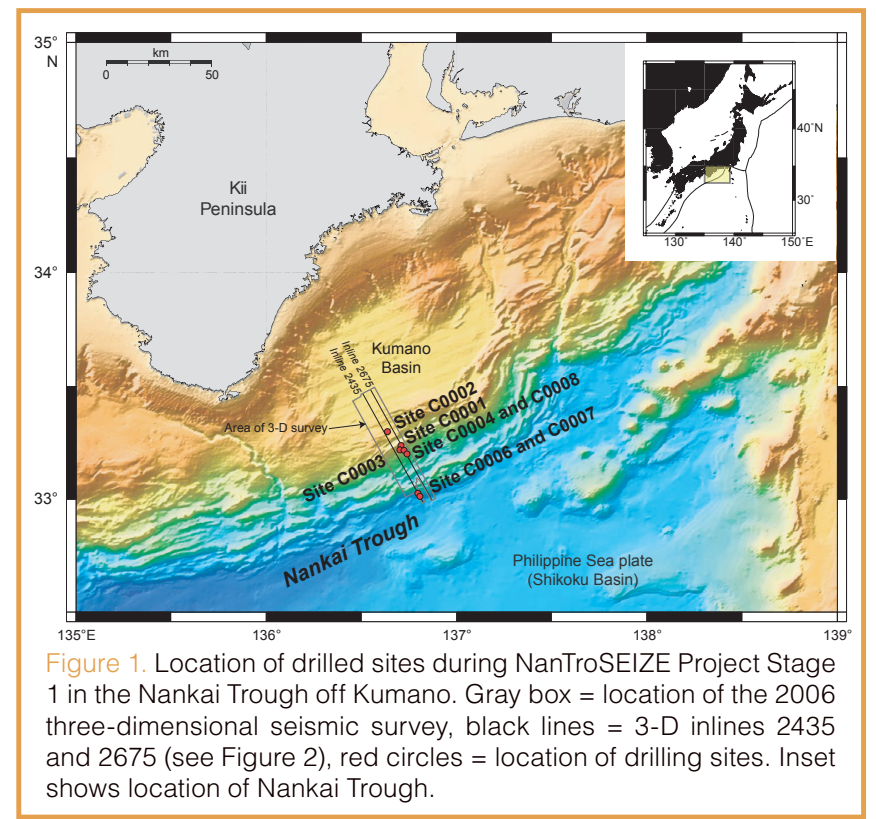

left Shingu port, Wakayama Prefecture, Japan, for her first scientific voyage as an IODP drilling platform. The start of NanTroSEIZE operations took place seven years after the first scientific proposals were submitted (see Kimura et al., 2003; Kinoshita et al., 2003; Suyehiro et al., 2003; Underwood et al., 2003; Screaton et al., 2005), and marked the culmination of thousands of hours of preparation and planning by a Project Management Team (PMT), the IODP Science Advisory Structure (SAS), and the CDEX engineers, technicians, and marine workers.

After 138 days of continuous operations, Stage 1 operations were completed on 5 February 2008. The overviews of each operation as well as the overall accomplishments of Stage 1 are described below. Preliminary reports for each of the expeditions have been published and posted on the Web (http://www.iodp.org/scientific-publications/).

\section{Expedition 314: LWD Transect}

Expedition 314, NanTroSEIZE Stage 1 LWD Transect, was planned to obtain a comprehensive suite of geophysical logs and other downhole measurements at six primary sites along a transect: two on the incoming plate, two through major active thrust faults, and two pilot holes for deeper riser drilling that also address scientific targets in the splay fault thrust sheet and the Kumano forearc basin and underlying prism.

Due to the difficulties experienced during attempted wireline logging and relatively higher success during limited LWD operations in previous accretionary prism drilling within ODP, Expedition 314 was entirely dedicated to the LWD effort. LWD tool selection focused on maximizing scientific returns from the tools and the time needed for deployment. The LWD tools used during Expedition 314 were state-of-the-art industrial tools, and this expedition marked the first ODP/IODP use of check shot interval velocity, and sonic velocity, and density/porosity measurements while drilling tools that have only been used on very limited occasions.

The operational plan included one-third of the total days (22.5 days out of 57 days) for contingencies (typhoons, mechanical downtime) and casing operations. Six primary and two contingency sites were planned for the expedition with the drilling order determined by scientific priority and 
operational difficulty. The location of planned sites and the order of drilling changed after the team faced various challenges. Allotted contingency days were consumed by expected mechanical downtime caused by the strong Kuroshio Current flowing through the area, by difficult drilling conditions, and by unforeseen mechanical and operational events.

During the eight-week LWD campaign, various

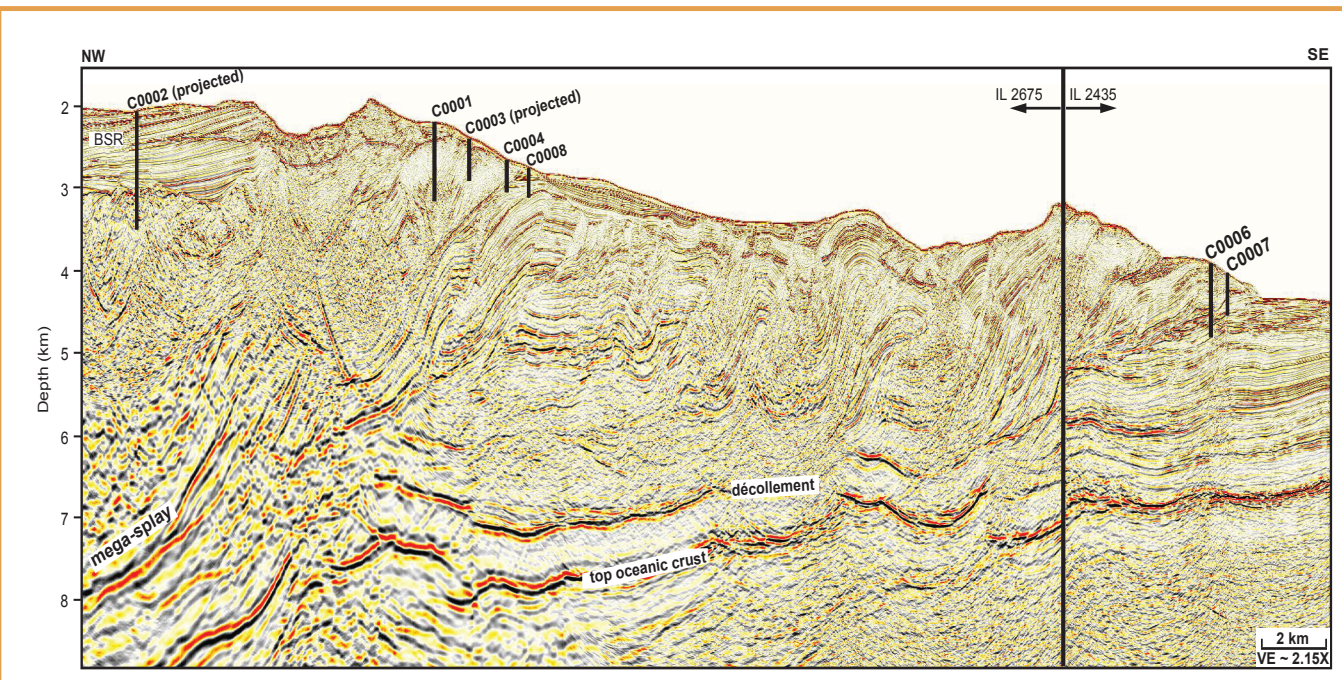

Figure 2. NW-SE slice through the NanTroSEIZE 3-D seismic survey (composite of 3-D Inlines 2435 and 2675) showing the projected locations of the sites, cored and logged during Stage 1. (Moore et al., 2007) measurements were suc-

cessfully completed at four of the twelve total drilled holes, with LWD data coverage ranging from $400 \mathrm{mbsf}$ to $1400 \mathrm{mbsf}$ (Fig. 3). Tool failure, loss of the Bottom Hole Assembly (BHA) due to borehole collapse, and pilot hole drilling (required for operational safety) consumed the remaining drilling time and accounted for the eight holes not fully logged. Logging data were initially analyzed by the shipboard scientists during the expedition in order to make the LWD data available to the scientific parties of the subsequent NanTroSEIZE Stage 1 coring expeditions (Exp. 315, 316). During the expedition, the shipboard science party worked in four groups: log characterization and lithologic interpretation, physical properties, structural geology and geomechanics, and core-log-seismic integration using various applications for log and seismic data analyses.

The principal results of Expedition 314 reveal a wealth of information about the accretionary prism, and provide a strong foundation for future planning of NanTroSEIZE, analysis of cores, downhole measurements, and observatory

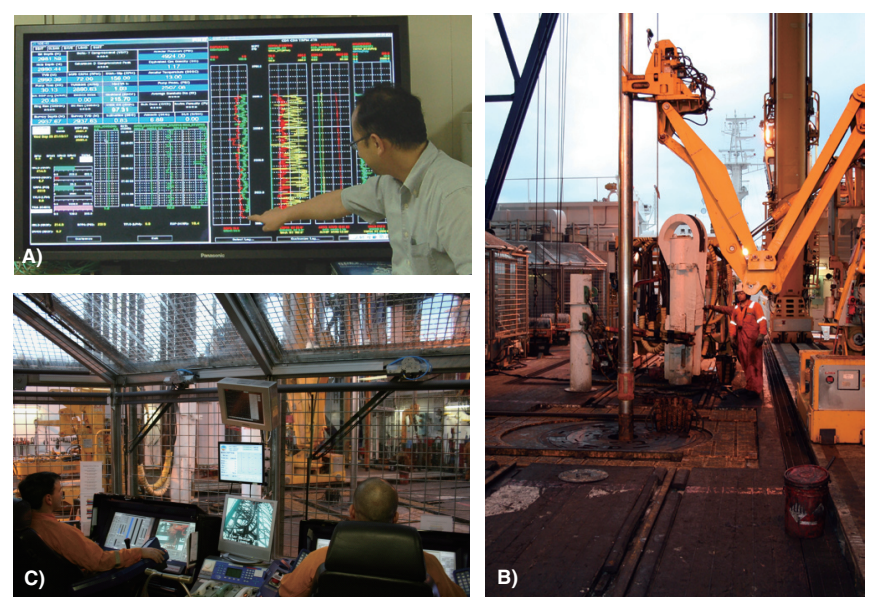

Figure 3. LWD drilling operations during Expedition 314. [A] Real time monitoring in the lab area; [B] LWD toolstring on the rig floor; [C] Driller's house operations. monitoring data. Additionally, these data provide a starting point for addressing questions raised about current models of the margin, including the composition and physical characteristics of the stacked thrust sheets comprising the prism, the distribution and character of the faults bounding the structural blocks and thrust sheets, information about the stress state in different areas across the margin, the distribution and occurrence of gas hydrates, and the characteristics of the sediments deposited in both the ancient, transported rocks and the more recent sediments draping the margin. Drilling of Sites C0001 and C0002 will also provide pilot hole information important in preparation for the planned deep-riser sites for later stages of NanTroSEIZE drilling.

\section{Expedition 315: Megasplay Riser Pilot}

IODP Expedition 315 took place between 16 November and 18 December 2007, planned as a geotechnical and scientific pilot study for future riser drilling of the megasplay fault (Fig. 2). Borehole LWD data obtained during Expedition 314 was available for use during Expedition 315; this proved extremely beneficial in planning for drilling, coring, and sampling of the scheduled operations.

The operational plan for the expedition was to drill and core to $1000 \mathrm{mbsf}$ at site C0001, a site considered for future riser drilling, then install riser top-hole casing in the latter half of the expedition. However, the Kuroshio Current was deemed to be running too strong (3-5 knots) to safely install the 36 -inch and 20 -inch casing strings required for the riser pilot. Drilling and operation plans were changed, and Expedition 315 was devoted to coring and downhole temperature measurement at two sites, C0001 and C0002 (Figs. 1 and 2). 
Coring at C0001 was conducted with the foreknowledge that the borehole conditions might deteriorate quickly at or near $500 \mathrm{mbsf}$, in the same formation that proved so difficult during Expedition 314 and where caving and borehole collapse resulted in the loss of the LWD BHA. Coring commenced with HPCS (hydraulic piston coring system) from the seafloor, and obtained good core recovery down to 230 mbsf, at which point coring was conducted using the ESCS (extended shoe coring system). Core recovery by HPCS was good (75\%-90\%); however, core quality using the ESCS was quite poor, and RCB (rotary core barrel) coring then commenced. Using the results of LWD, we expected to encounter a zone of drilling difficulty and borehole instability around 450-600 mbsf. Accordingly, the strategy was to wash down to and through this formation and try to core the formations below that. We succeeded in drilling down to the target depth; however, caving and borehole collapse began nearly immediately, precluding attempts to core below the unstable region.

Because riser top-hole casing operations were postponed due to the intense current, Site C0002 in the Kumano Basin was chosen for coring, and it was decided that the deeper section was the most critical target. RCB coring began after drilling down to $475 \mathrm{mbsf}$, and sixty-six cores were collected from that point down to the total depth. We penetrated the basal unconformity of the Kumano basin at 922 mbsf and continued more than $100 \mathrm{~m}$ into accretionary prism materials with moderate recovery. As borehole conditions steadily worsened deeper in the accretionary prism, the hole was abandoned at $1057 \mathrm{mbsf}$. Two short coring operations using the HPCS system were conducted between the seafloor and $204 \mathrm{mbsf}$ for both geotechnical investigations and for scientific data collection.

As the first coring expedition for the Chikyu, Expedition 315 provided valuable scientific and geotechnical data that will be critical in understanding the Nankai accretionary

prism off the Kii Peninsula. In addition, the expedition proved to be invaluable in terms of improving drilling, management, and laboratory performance under harsh weather, strong current, and unfavorable operational conditions. The drilling conditions encountered at intermediate depths at C0001 and C0002 provide important constraints on riserless drilling operations in the fractured and faulted formations that comprise much of the shallow prism, and they will provide data necessary to plan future drilling, coring, and casing operations. Critical scientific data was acquired from the upper part of the accretionary prism at both sites, including geological (lithology, structure, and age), geotechnical (physical properties, temperature) and geochemical information for the accretionary prism materials (Fig. 4). These data will help planning for the engineering and scientific aspects of future riser drilling.

\section{Expedition 316: Shallow Megasplay and Frontal Thrusts}

IODP Expedition 316 drilled several sites in a transect across the outer part of the Nankai accretionary prism. The aims of the expedition were to characterize the sedimentology, stratigraphy, and physical properties of the slope sediments, the accretionary prism rocks, and the underthrust material, and to sample and understand the character of fault rocks within fault zones controlling the geometry and evolution of the accretionary prism.

We targeted two major structures: the frontal thrust (sites C0004 and C0008) and the shallow portion of the megasplay fault zone (sites $\mathrm{C} 0006$ and $\mathrm{C} 0007$ ) near its intersection with the seafloor (Figs. 1 and 2). Comprehensive sampling and measurement both in boreholes and on core materials were carried out, including downhole temperature measurements, interstitial water sampling, microbiological sampling, gas sampling, and a wide array of sampling for chemistry, mineralogy, and physical properties. More than 1300 meters
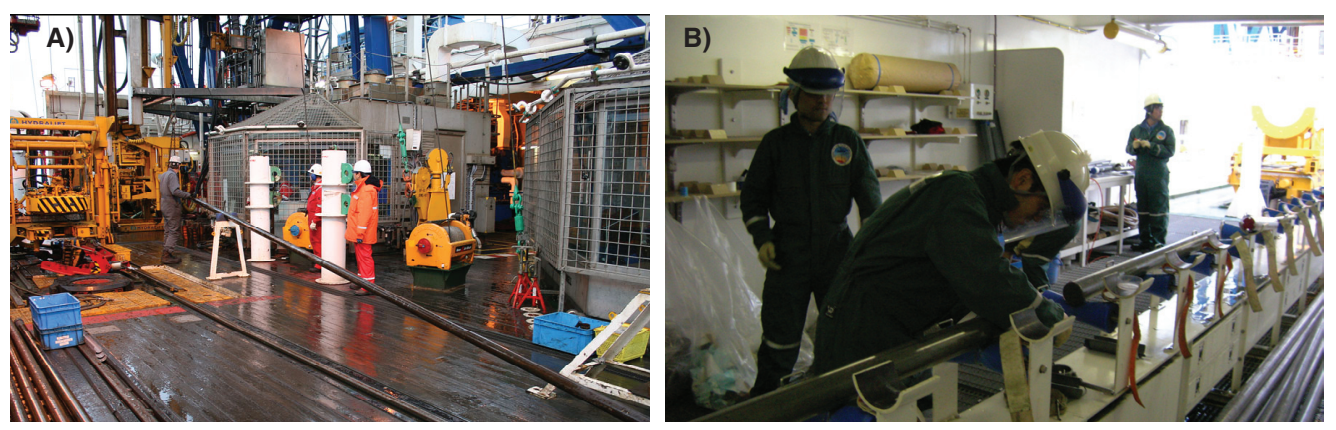

Figure 4. Coring and laboratory operations during Expedition 315. [A] Core barrel being laid out on the drill floor prior to removal of the collected core. [B] Laboratory technicians cutting a core into sections and collecting safety and time-sensitive samples prior to delivery of core section to the core lab. [C] Core section being run through the X-ray CT scanner. [D] X-ray CT image of a small fault zone cutting across interbedded mud (dark areas) and sandy ash (bright areas).
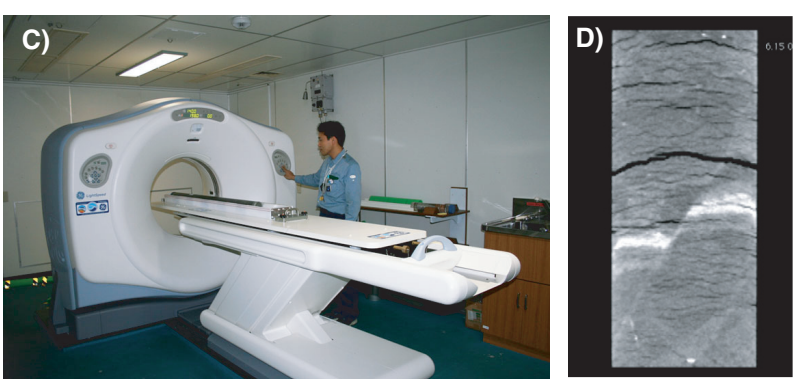

of core were recovered using HPCS, ESCS, and RCB. More than 5000 samples were taken from the cores for shore-based investigation, and many thousands of continuous and discrete measurements were carried out using the array of laboratory tools on board the Chikyu.

We successfully recovered a wide array of fault rocks from fractured rocks to breccia to fault gouge, sedimentary materials ranging from fine clay and mud to siltstone and sand, and we 
managed to recover extremely coarse grained materials from paleo-trench-axis channels. Materials sampled include recent slope apron/slope basin deposits (including several mass transport complexes that may shed light on the periodicity of slope failure), ancient accretionary prism rocks, and material that has been over-ridden during thrust faulting events (Fig. 5). Analyses of these wide-ranging data sets will shed new light on the evolution, structure, and architecture of the Nankai accretionary prism off the Kii Peninsula.

\section{Overview and Primary Accomplishments}

Chikyu accomplished an LWD and two coring expeditions in a transect across the Nankai Trough accretionary prism, gathering large volumes

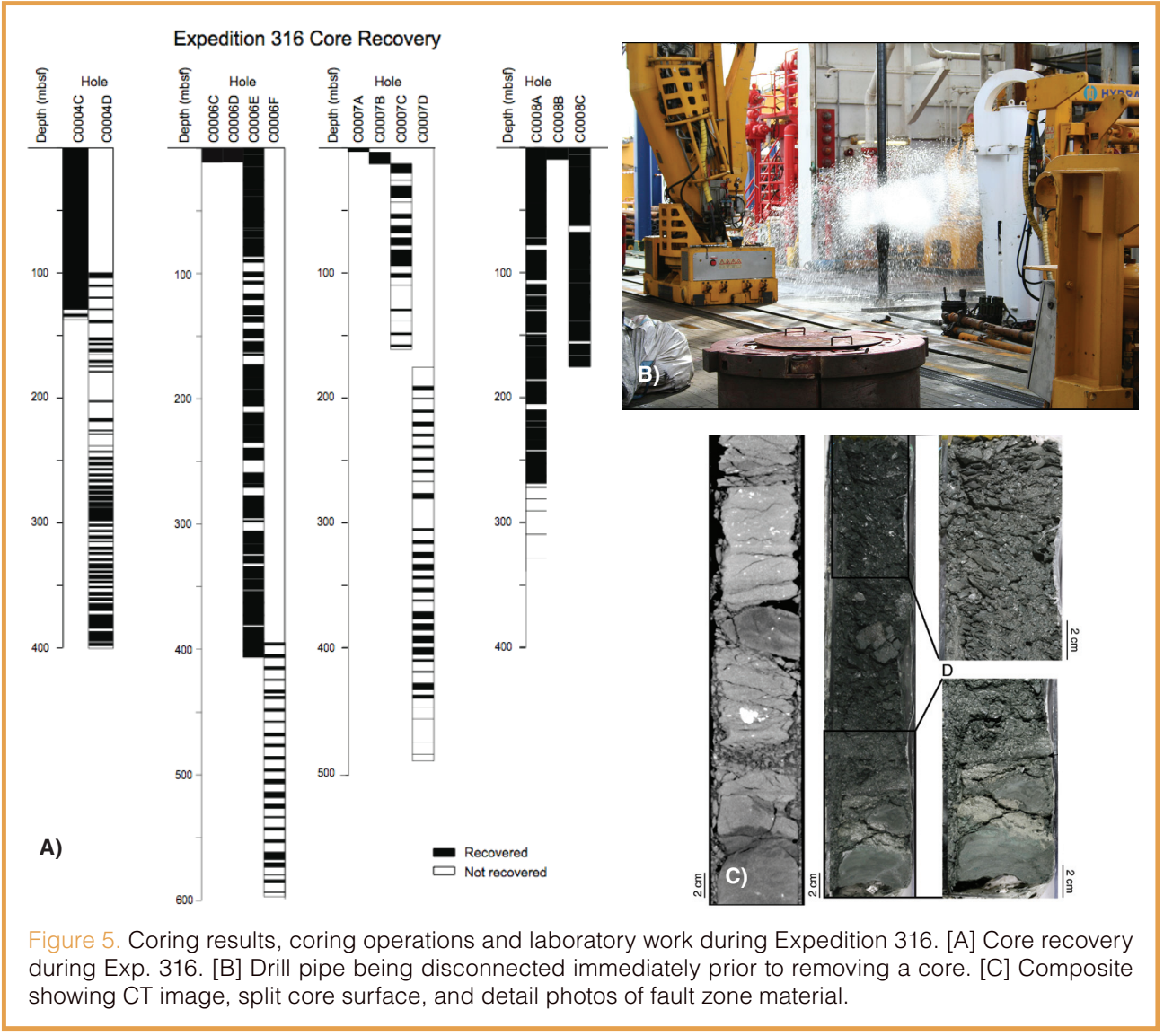
of data, cores, and samples that will help understand the structure and mechanics of the shallow accretionary prism, and that will aid in planning and carrying out future deep drilling to the shallow part of the lying 6-7-km-deep seismogenic zone.

Expedition 314 (LWD Transect) collected $4274 \mathrm{~m}$ of LWD logs and conducted $2285.5 \mathrm{~m}$ of MWD $\log$ s from pilot holes. Expedition 315 (Megasplay Riser Pilot) penetrated $1287 \mathrm{~m}$ and recovered $808 \mathrm{~m}$ of core. Expedition 316 (Megasplay and Frontal Thrusts) penetrated $2103 \mathrm{~m}$ and recovered $1340 \mathrm{~m}$ of core. Total drilling length was approximately $12,800 \mathrm{~m}$, and total attempted coring was about $3400 \mathrm{~m}$ with an average core recovery rate of about $65 \%$. All cores have been archived for preservation, future description, and sampling at the Kochi Core Center (KCC), one of the three IODP core repositories.

During the course of these expeditions, Chikyu was able to test and refine operational techniques and structures that are well-established components of the ODP/IODP operational paradigm, but that are still relatively untested on this newest platform for scientific ocean drilling. These include severe, real-world tests of the Dynamic Positioning system, drilling, coring, and laboratory systems, expedition management, safety monitoring, and onboard operational safety and communications infrastructure. In addition, Chikyu was able to pioneer the use of new tools and equipment, including the scientific use of never-before-used LWD tools, testing of new coring systems and techniques, testing of new

downhole temperature measurement tools, and extensive use of X-ray Computed Tomography (XCT, Fig. 6) on whole core sections. The use of XCT scanning in particular proved to be an exciting and revolutionary addition to the scientific drilling, as it allows inspection of core before any destructive measurement or sampling is carried out, provides real-time guidelines for sampling and handling before the core is split, and allows the identification of critical intervals for special handling. In addition, the use of XCT imaging to construct pseudo-density logs (using the "CT number" which is a semi-quantitative proxy for bulk density), to measure faults and fractures, and to identify unconformities and fine-scale details provided exciting results on board and opened a new avenue for extensive post-expedition research.

While shipboard and shore-based scientists from the NanTroSEIZE Stage 1 expeditions have already begun analyzing the huge volume of data taken from LWD and core measurements, studies for future deep riser drilling, in terms of geomechanical modeling and borehole stability, are underway in CDEX in collaboration with industry and research specialists.

An immense amount of work has been required to prepare the Chikyu for IODP science operations. While it is clear that there is a lot of further effort required to develop the fullest potential of the vessel and its laboratories, when we take into account the successes, problems, and challenges experienced during NanTroSEIZE Stage 1, the results of these three 
expeditions give us great confidence in the future of IODP operations using the Chikyu.
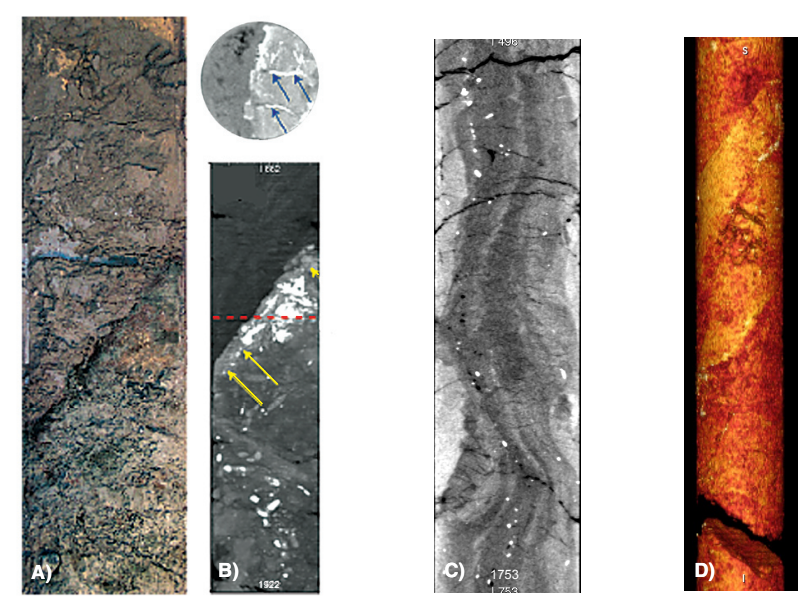

Figure 6. Usage and results from the X-ray computed tomography analyses. [A] Selected $X$-ray CT images. [B] The relationships that can be seen between the core photos and the CT images; Yellow and blue arrows indicate the position of the clear discontinuity seen in both core and CT image, with bright areas corresponding to mineralized material. The red line in the along-core CT image shows the position of the slice in the upper right. Spatial and angular relationships can be determined with high precision using core orientation. [C] X-ray CT imagery can be used to evaluate coring induced or drilling induced deformation or disruption of the core sample. This image shows flow-in of fluidized mud that occurred during core recovery of a piston core. [D] False color imagery based on CT-number (density contrasts related to pore spaces, water content, and mineral chemistry) can be used to highlight structural features such as this set of normal faults (cutting the core from top right to bottom left in this image). In all cases, cores are 2.5 inches across.

\section{Acknowledgements}

We would like to thank the Japanese Ministry of Education, Culture, Sports, Science and Technology (MEXT) for funding Chikyu, and to the host of staff, technical workers, managers, and operations personnel in all the various departments and agencies at JAMSTEC, at CDEX, at TAMU, at the ESO, and within the global science community for the work, advice, efforts, and support required to begin this scientific endeavor with such success. Great thanks are owed to the crew of the Chikyu, the drilling crew and operational teams, the helicopter pilots, shorebased support staff and supply vessel crews, the technical and design teams who helped construct and test the vessel prior to IODP operations, to the science parties and laboratory staff, and to the enormous number of technicians, scientists, designers, programmers, and engineers who have contributed so much of their time, expertise, and advice to the preparation and execution of the first successful IODP operations of the Chikyu.

\section{References}

Kimura, G., Tobin, H., and the NanTroSEIZE working group, 2003. NanTroSEIZE: The Nankai Trough Seismogenic Zone Experiment Complex Drilling Project. IODP-603 CDP3, revised proposal received 1 October 2003.
Kinoshita, M., Brown, K., Saffer, D., Henry, P., Chester, F., Goto, T., Gulick, S., Hirono, T., Ito, H., Kato, A., Kimura, G., Kopf, A., Moore, G., Moore, J.C., Nakamura, Y., Park, J.-O., Saito, S., Schwartz, S., Shinohara, M., Stephen, R., Tobin, H., Ujiie, K., Tsunogai, U., and Yamano, M., 2003. NanTroSEIZE Drilling and Observatory Phase 2. Mechanical and Hydrologic State of Mega-Splay Faults: Implications for Seismogenic Faulting and Tsunami Generation, IODP 603BFull 2, revised proposal received October 2003.

Moore, G.F., Bangs, N.L., Taira, A., Kuramoto S., Pangborn, E., and Tobin H., 2007. Three-dimensional splay fault geometry and implications for Tsunami generation. Science., 318(5853):1128-1131, doi:10.1126/science.1147195

Screaton, E., Underwood, M., Saffer, D., Wang, K., Wheat, G., Obana, K., Moore, G., Brown, K., and Ashi, J., 2005. The Nankai Trough Seismogenic Zone Experiment: Observatory Science at the Reference Sites. IODP 603D-Full2, revised proposal received April 2005.

Suyehiro, K., Tobin, H., Araki, E., Bilek, S., Goto, T., Henry, P., Kimura, G., Kato, A., Kinoshita, M., Marone, C., Moore, G., Moore, J. C., Saffer, D., Sakaguchi, A., Shinohara, M., Stephen, R., Tsutsumi, A., Ujiie, K., and Wang, K., 2003. NanTroSEIZE Drilling and Observatory Phase 3: A Window into the Seismogenic Zone. IODP 603C-Full, revised proposal received October 2003.

Tobin, H.J., and Kinoshita, M., 2006. Investigations of seismogenesis at the Nankai Trough,Japan. IODP Sci. Prosp., NanTroSEIZE Stage 1. doi:10.2204/iodp.sp.nantroseize1.2006. Available online at http://publications.iodp. org/scientific_prospectus/NanTroSEIZE_stage1/.

Underwood, M., Ashi, J., Soh, W., Morgan, J., Saito, S., Saffer, D., Screaton, E., Kinoshita, M., Moore, G., Kastner, M., Bilek, S., and Ujiie, K., 2003. NanTroSEIZE Reference Sites: Sampling and Measuring Inputs to the Seismogenic Zone, IODP 603A-Full2, revised proposal received April 2003.

\section{Authors}

Shin'ichi Kuramoto, Daniel Curewitz, Moe Kyaw Thu, Hideki Masago, JAMSTEC, Yokohama Institute of Earth Sciences, 3173-25 Showamachi, Kanazawa, Yokohama 2360001 Japan, e-mail: s.kuramoto@jamstec.go.jp; daniel@jamstec.go.jp; moe@jamstec.go.jp; masagoh@jamstec.go.jp. and the Exp. 314, 315, and 316 Science Parties

\section{Related Web Link}

http://www.iodp.org/scientific-publications/

\section{Figure and Photo Credits}

All photos courtesy of IODP and CDEX. 